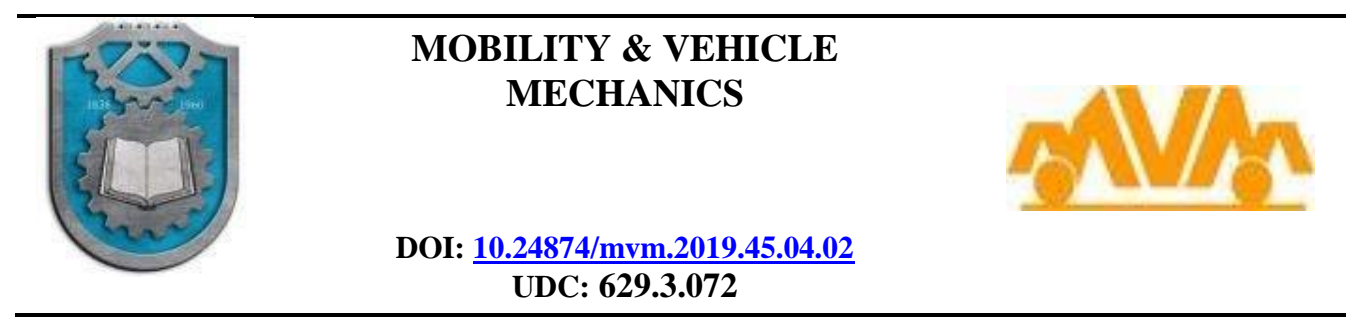

\title{
TOUCH SCREEN CAR DASHBOARDS AS SERIOUS DANGER FOR CAUSING TRAFFIC ACCIDENTS
}

\author{
Janez Kopač ${ }^{1 *}$, Franci Pušavec ${ }^{2}$ \\ Received in October $2018 \quad$ Accepted in December 2018 \\ RESEARCH ARTICLE
}

\begin{abstract}
More and more sophisticated cars have also very modern cockpit boards full of information, with many buttons, touch-screen interactions, commands on steering wheel, radio, $\mathrm{A} / \mathrm{C}$, etc. We know how dangerous alcohol is and its influence on prolonging driver's reaction time. In recent years, there is also a strong action against using a phone during driving. Searching through the phone menu is taking attention off the road. Similarly, drivers with new cars need several months to learn approximately where particular/some commands can be found. We have measured time periods necessary to find different commands. For example, activating A/C takes $1.0 \mathrm{~s}-2.0 \mathrm{~s}$. In the case of car moving with speed of $50 \mathrm{~km} / \mathrm{h}$ through the city, this means traveling along a path of $14 \mathrm{~m}-28 \mathrm{~m}$ without any control (by speed of $120 \mathrm{~km} / \mathrm{h}$, this corresponds to $33 \mathrm{~m}-66 \mathrm{~m}$ ). Additional fact is also the existence of a red triangle emergency button that is becoming smaller and smaller and thus poorly visible in new cars. To find this button, driver again needs more than one second in most critical situations, when full concentration focused on the road is needed. This paper presents different car dashboards and measured necessary times for obtaining control. Results are followed by discussion and the suggestions to the drivers how to deal with the raised problem.
\end{abstract}

KEY WORDS: cars, dashboard, control buttons, touch screen, lost time, reaction path

C 2019 Published by University of Kragujevac, Faculty of Engineering

${ }^{1}$ Janez Kopač, PhD prof., University of Ljubljana, Faculty of Mechanical Engineering, Aškerčeva c. 6, 1000 Ljubljana, janez.kopac@fs.uni-lj.si (*Corresponding author)

${ }^{2}$ Franci Pušavec, Assoc. prof., University of Ljubljana, Faculty of Mechanical Engineering, Aškerčeva c. 6, 1000 Ljubljana, franci.pusavec@fs.uni-lj.si 


\section{INSTRUMENTALNE TABLE AUTOMOBILA SA EKRANOM OSETLJIVIM NA DODIR KAO VAŽNA OPASNOST ZBOG IZAZIVANJA SAOBRAĆAJNIH NEZGODA}

REZIME: Sve više sofisticiranijih automobila takođe poseduju veoma moderne table za pilotske kabine pune informacija, sa mnogo tastera, interakcije sa dodirnim ekranom, komande na točku upravljača, radija, klima uređaja itd. Znamo koliko je opasan alkohol i njegov uticaj na produženje vremena reakcije vozača. Poslednjih godina je takođe snažna akcija protiv upotrebe telefona tokom vožnje. Pretraga kroz meni telefona skreće pažnju sa puta. Slično tome, vozačima novih automobila potrebno je nekoliko meseci da nauče otprilike gde se mogu naći pojedine komande. Izmerili smo vremenske periode potrebne za pronalaženje različitih komandi. Na primer, za aktiviranje klima uređaja potrebno je 1,0 $\mathrm{s}$ $2,0 \mathrm{~s}$. U slučaju da se automobil kreće brzinom od $50 \mathrm{~km} / \mathrm{h}$ kroz grad, to znači da se kreće stazom od $14 \mathrm{~m}-28 \mathrm{~m}$ bez ikakvog nadzora (brzinom od $120 \mathrm{~km} / \mathrm{h}$, to odgovara $33 \mathrm{~m}-66$ m) . Dodatna činjenica je i postojanje crvenog dugmeta za hitne slučajeve koji je sve manji i manji, a samim tim i slabo vidljiv u novim automobilima. Da bi pronašao ovo dugme, vozaču ponovo treba više od jedne sekunde u najkritičnijim situacijama, kada je potrebna puna koncentracija usmerena na put. $U$ ovom radu su prikazane različite komandne table automobila i izmerena potrebna vremena za dobijanje kontrole. Rezultate prati diskusija i sugestije vozačima kako da se izbore sa postavljenim problemom.

KLJUČNE REČI: automobili, komandna tabla, kontrolni tasteri, dodirni ekran, izgubljeno vreme, reakcije puta 


\title{
TOUCHSCREEN CAR DASHBOARDS AS SERIOUS DANGER FOR CAUSING TRAFFIC ACCIDENTS
}

\author{
Janez Kopač, Franci Pušavec
}

\section{INTRODUCTION}

The study on the use of mobile phones by the drivers shows problematical situations in using them during driving. As an answer to the safety issues, there appear some alternatives like: driving mode on the phone allowing just incoming calls, hands-free installation in the car, voice commands, etc. Even though they have their advantages, none of those solutions assures a $100 \%$ safe usage of the phone during driving. Still, in most cases, this is not serial equipment of the car - many drivers still hold mobile phones simply in hand, without any hands-free connection with car radio system. On one side, this is taking their attention from the road to the phone. However, at least they normally hold the phone between the head and the steering wheel. In this way, they partially see the road and traffic in front of them. This is not perfect, but still much better than searching/typing on the touchscreen located on the right side of the driver, thus the driver must physically look away for approximately $35^{\circ}$ from the direction of driving. This means losing the attention from the road for 1.0-2.5 s. Depending on the driving speed, this time corresponds to the path that car drives without attention of the driver [4].

In addition, the important dilemma has been raised related to the question how many commands it is really necessary to have on the dashboard and which of those can be really adjusted during driving? However, the trend seems to go in other direction. The dashboards in new cars are going to be totally digital in parallel with the request from EU commission to assure higher traffic safety.

The new developed cars are going to be completely autonomous with a lot of electronic support/active supervision systems: active adaptive cruise control/breaking system, road line assistant, speed assistant, etc. Those systems are adding a stone to the traffic safety. However, it will take a long time (approx. 20 years) for all cars to be equipped with such technology. Basically, it is going to take the car lifetime. Just after the old cars will reach their lifetime, they will be changed with the modern ones.

\section{SOME CASES OF COCKPITS AND THEIR SPECIFICATIONS}

A multifunction steering wheel, equipped with $4+1$ different control handles, offers wide control options. However, the number of control varieties is also enhancing the complexity and time to adjust lights, gear transmission, cruise control, windshield wiper, etc. Advantage of a cockpit shown in Figure 1 is a big digital speed display and a big button for switching the warning emergency lights, in the middle of a dashboard pillar. However, simple search for air circulation control can then take a lot of time. It can be expected that the driver spends $1-3 \mathrm{~s}$ for this action. Figure 1 shows an example of a very transparent speed indicator on top positioned display that offers no need to search downwards and to the right side, but it is directly in the line of the driving direction. 


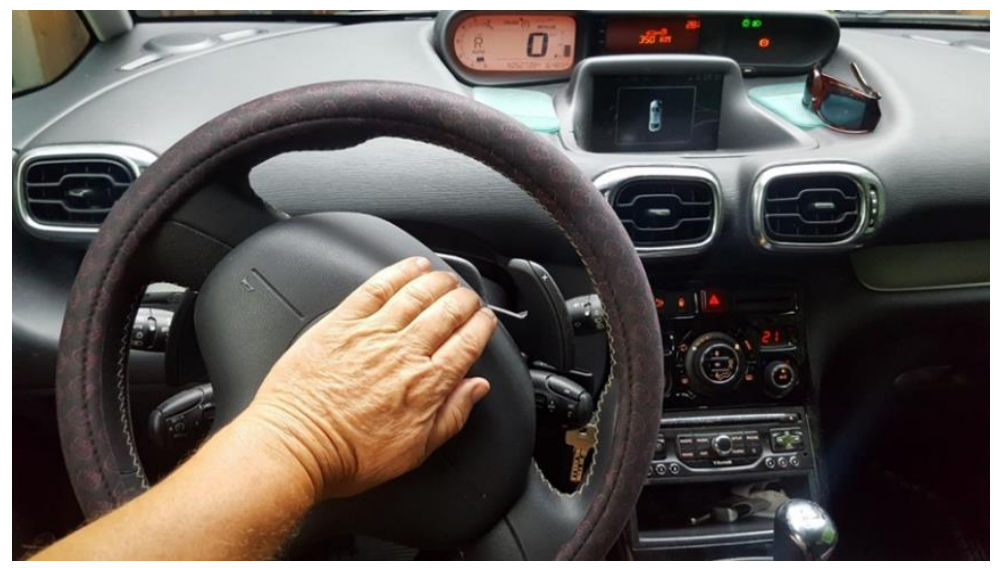

Figure 1. Cockpit of car A with many options - all functions are activated by mechanical switches/buttons

On the contrary, Figure 2 shows the steering wheel with many commands that is obstructing the view of the dashboard.

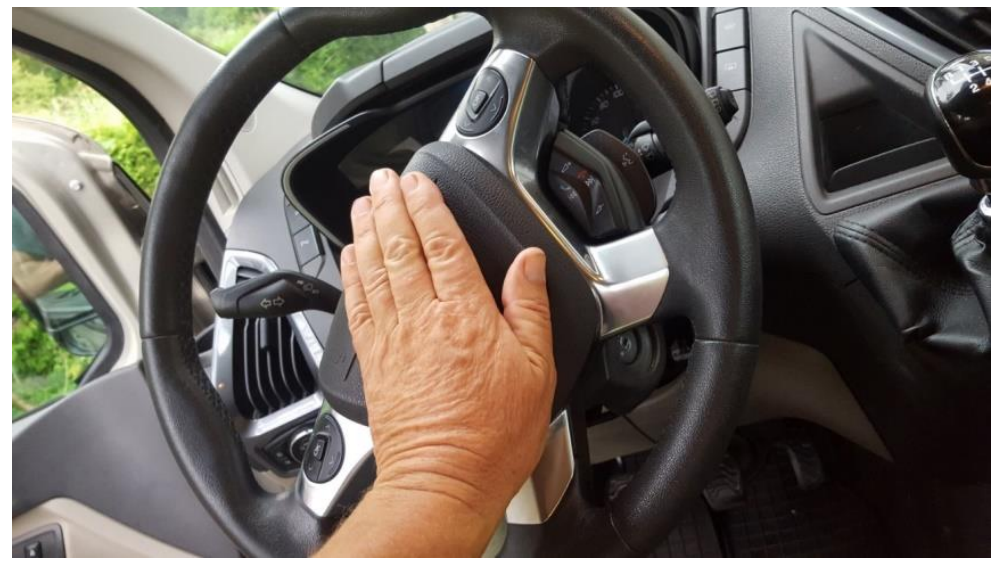

Figure 2. Cockpit of car B with many controls on the steering wheel obstructing the view of the dashboard

In the case shown in Figure 3, during driving with speed limit (for instance, in the city, where speed limit is $50 \mathrm{~km} / \mathrm{h}$ ), the average time for adjusting the most common settings in the car amounts between 1.5-2.0 s [3]. This confirms the suspicion that the modern cars offer a lot of command possibilities with the drawback in attention that has to be taken from the road and, in most cases, put on the touchscreen commands for a couple of seconds. One of the solutions that would help improving this issue could be in the system for track control by video sensing system. 


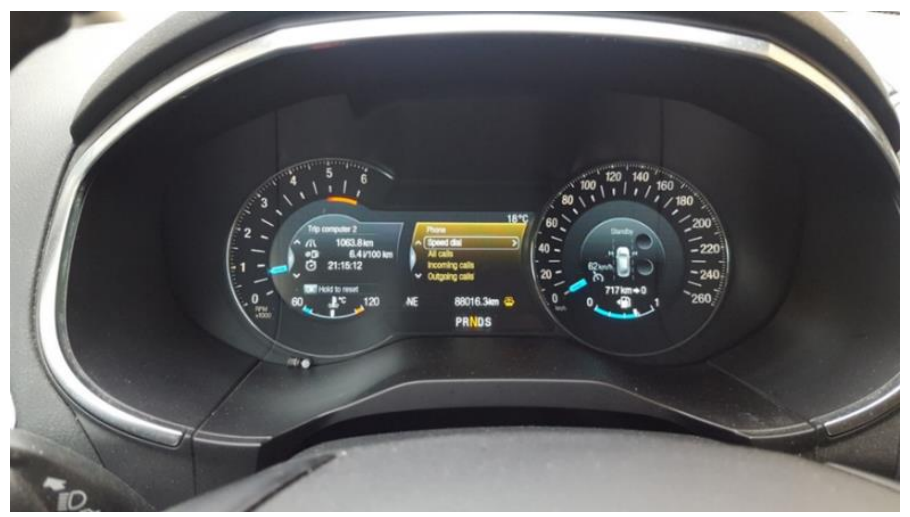

Figure 3. Cockpit of car B with digital dashboard

Some modern cars even have many more systems, equipment, commands, mechanical switches and touchscreen commands. It is a fact that being able to control all of them takes time to recognize them, remember and scroll their positions. Especially, searching the position of the desired command during driving can be very dangerous. It is well known that, in sophisticated cars, drivers need to drive them for $50,000 \mathrm{~km}$ or use them for 2 years, before they are completely comfortable with their usage and are even capable to automatically use some of the commands, without removing the attention from the road [1, 5]. Even the emergency buttons - triangular buttons for blinking lights can be problematic. In Figure 4, two options are presented: the conventional command panel (right) and the touchscreen command panel (left). In addition to the aforementioned differences, a comparison between triangular emergency blinking lights switches is interesting. It seems that, with modern cars, the size of this switch is decreasing. This should not be the case, because it is clear that this switch can be used in the most critical situations, where size should not influence the critical moments. In extreme cases (Figure 5), modern dashboards can even be made so that there is not a single button switch present any more.
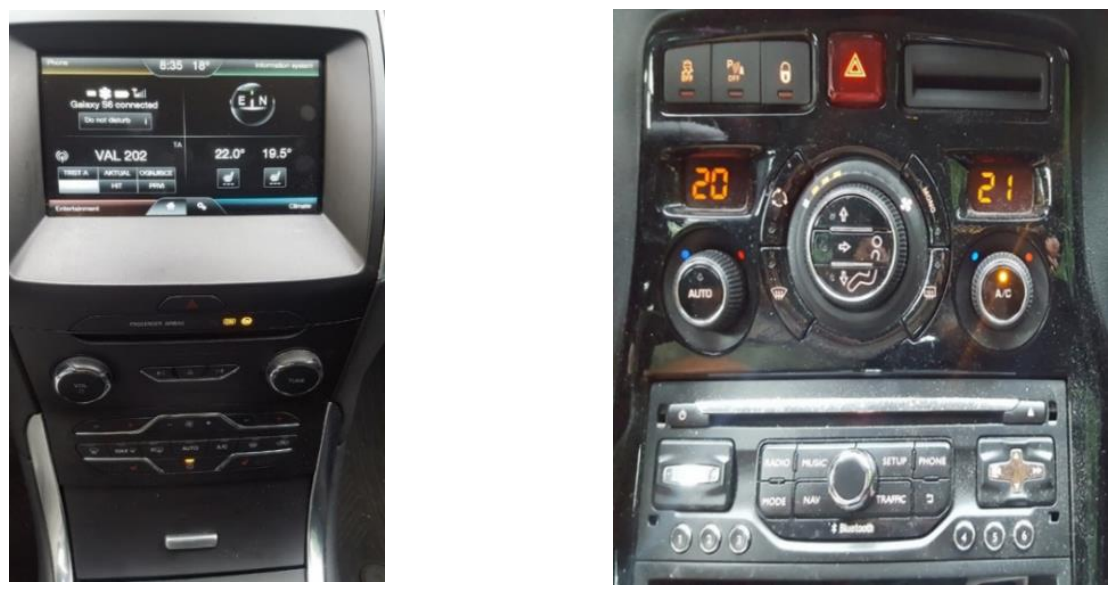

Figure 4. Comparison of B (left) and A (right) car cockpits and ease of access to the triangle warning button 


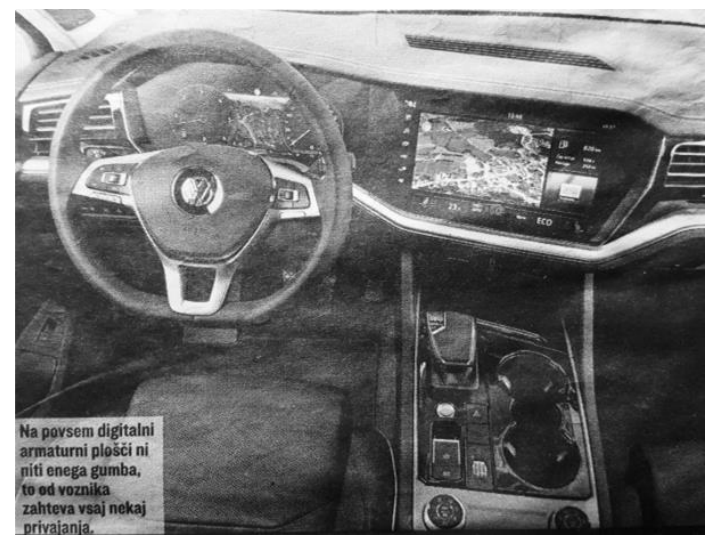

Figure 5. Totally digital dashboard as an answer to request for higher traffic safety

\section{CONCLUSION AND FURTHER RESEARCH}

"Principle of Trust" between the drivers on the road is actually stronger then between husband and wife in the family. Drivers are driving against each other on a narrow roads, with speeds up to $90 \mathrm{~km} / \mathrm{h}$. In the case of an accident, this would present the impact speed that is double, i.e. $180 \mathrm{~km} / \mathrm{h}$. In other words, such speed corresponds to the approaching path of $50 \mathrm{~m}$ in every second [2]. In such cases, every tiny part of a second that the attention of the driver is lost from the traffic by checking instruments on the dashboard can be crucial/critical. On normal roads, traffic lanes are narrow and they can have $2.5 \mathrm{~m}$ of width. In such cases, with attention not on the road, car can reach the opposite lane in approximately $0.5 \mathrm{~s}$, if the steering wheel deviates $10^{\circ}$ from the direction of the road. Thus, in the case when belief, trust and attention are not present, even luck can hardly prevent occurrence of a car crash. Modern cars will in those critical situations help a lot with indication of critical moments, with automatic breaking, etc. However, attention of the driver to the traffic is and will always be the most important parameter rescuing the critical moments that can happen in the traffic.

\section{REFERENCES}

[1] Burg, M., Moser, A.: "Handbuch Verkehrsunfallrekonstruktion. Unfallaufnahme, Fahrdynamik, Simulation", ATZ/MTZ-Fachbuch, Vieweg+Teubner Verlag, 2007, Wiesbaden.

[1] Kuhelj, A.: "Mehanika, kinematika", Lecturing handouts, Faculty of Mechanical Engineering, 2010, Ljubljana.

[2] Johnson, K., Krejan, A.: "Fizika: preproste razlage fizikalnih pojavov", Tehniška založba Slovenije, 2007, Ljubljana .

[3] Kostić, S.: "Ekspertize saobračajnih nezgoda", Fakultet tehničkih nauka, 2016, Novi Sad.

[4] De Smet, A.: "Transportation Accident Analysis and Prevention", Nova Science Publishers, 2008, New York. 